\title{
ACCIDENT AT WORK AS AN INDICATOR SUPPORTING THE DECISION MAKING PROCESS
}

doi: $\quad 10.2478 /$ czoto-2019-0011

Date of submission of the article to the Editor: $17 / 11 / 2018$

Date of submission of the article to the Editor: 22/12/2018

Agnieszka Strzelecka ${ }^{1}$ - orcid id: 0000-0002-6030-0860

Marzena Pytel-Kopczyńska ${ }^{1}$ - orcid id: 0000-0001-8850-8586

Milan Droppa ${ }^{2}$ - orcid id: 0000-0001-9406-5267

${ }^{1}$ Czestochowa University of Technology, Poland, agnieszka.strzelecka@wz.pcz.pl, marzena.pytelkopczynska@wz.pcz.pl

${ }^{2}$ Catholic University in Ružomberok, Slovakia

Abstract: Identification of trends of the examined phenomenon plays a major role in taking decisions and allows conducting a deeper analysis of phenomena connected with the shaping of proper working conditions. One of the result indicators in the OSH system is the accident rate, whose existence is the result of a combination of various events. Seeking tangible economic benefits, decision makers in business entities who wish to improve activities protecting health and life of employees, pay great attention to using quantitative methods and drawing conclusions from them. This is conditioned by the fact that the analysis of the economic aspects of accidents is connected to a large extent with the cost of benefits the employer incurs for the benefit of accident victims. Therefore, the main goal of the article is to examine what impact on the cost of benefits due to accidents at work is exerted by such factors as: the number of related benefits, persons injured in accidents at work depending on the consequences and the number of days of inability to work caused by these accidents. Furthermore, this paper shows changes in costs of accident benefits of persons receiving those benefits due to inability to work caused by accident in business. In order to achieve this, it is proposed to present an econometric analysis based on the cross-sectiontime data with the dynamics of considered variables in voivodeships in Poland being examined. The study uses the annual data for the years 2010-2017. The data come from the CSO publications.

Keywords: accident at work, cost of benefits due to accidents at work, a space-time model

\section{INTRODUCTION}

The dynamically changing organisation's environment as well as economic and social conditionings require that numerous aspects of man's functioning in the working environment are constantly controlled. Working conditions determine the quality of professional life and their consequences exert a huge impact on the whole life of an 
individual (European Commission, 2011). Illnesses, disability, burnout or just tiredness that leads to decreased engagement in work constitute a loss not only for affected employees themselves and their families, but they also contribute to widely perceived losses and economic and social costs related to them. The multifaceted nature of the issues related to costs of work safety with regard to analyses of accident ratios causes that it becomes an object of interest both at the level of enterprise, region or industry functioning as well as on a national or global scale with reference to the whole area of the European Union (Bellamy et al., 2014; Carrillo-Castrillo et al., 2013). What is important the EU's strategy in the area that concerns employment and social affairs, which was expressed in the primary document, i.e. the Treaty establishing the European Community in Article 137, stresses the fact that protection of health and safety of employees is one of the key elements of the common policy adopted by member states (Treaty establishing EC).

Therefore, the knowledge on the scale of costs that result from unexpected and undesirable occurrences triggered by external reasons that lead to an injury or death, which took place in relation with work, as well as their most relevant factors should constitute a precisely defined priority at every decision-making level (Battaglia et al., 2014). An honest analysis of safety costs incurred by employees, employers and the whole society, identifying the structure and mutual dependencies of these costs becomes a basis of effective management and reference point for the reasonability of remedial actions and widely understood prevention (Bayram et al., 2017; Bayram and Ungan, 2018).

With this in mind, the underlying goal of the authors have been to model costs of benefits in respect of accidents at work depending on the factors that condition them, in the context of decision-making processes optimisation in the scope of prevention actions.

\section{METHODOLOGY OF RESEARCH}

An analysis of economic aspects of accident ratios is to a large extent associated with the cost of benefits that employers incur on behalf of an employee injured in an accident. Due to the fact that employers find information that derives from econometric models useful the paper includes an analysis where costs of benefits in respect of accidents at work have been conditioned by its main determinants. In addition, the authors have demonstrated the dynamics of the accident ratio compared to the previous year, the share of injured persons in relation to the effect of an accident in the total number of these persons and the development of accident pensions costs in case of persons being paid such pensions due to their inability to render work for the reason of an accident at work.

The time and space analysis includes an econometric model, uses cross-section-time data, and the results have been obtained with the use of a panel model - the objects (I) constituted Polish provinces (voivodeships) and the time $(t)$ comprised years 20102017. The basis for comparisons was the number of working persons in each of the provinces, and the data expressed in the currency unit has been converted into fixed prices from the year 2010.

Considering the work specificity, it has constituted the focus of the aspects economy. Thus, the econometric research aimed at assessing the cost of benefits due to accidents at work (KSWP) initially included the variables that make such an assessment possible, that is: 
- number of benefits in respect of accidents at work - SDWP (in items/1000 employed persons in the province);

- victims of fatal accidents at work - PWSP (in persons /1000 employed persons in the province);

- injured in serious accidents at work - PWCP (in persons /1000 employed persons in the province);

- injured in lighter accidents at work - PWLP (in persons/1000 employed persons in the province);

- number of days being incapable to work resulting from an accident at work DNWP (in days/1000 employed persons in the province).

However, a preliminary research has demonstrated that among the proposed variables only the number of benefits and the number of days being absent from work due to accidents at work can be analysed together. This is the outcome of the fact that while analysing the dependencies between the variables it turned out that the injured and the remaining determinants were dependent one on another. Thus, such a situation excludes considering all these factors in one equation.

In the light of the above, the following form of the model has been proposed to describe the explained variable:

$$
K S W P_{i t}=\alpha_{0} S D W P_{i t}^{\alpha_{1}} D N W P_{i t}^{\alpha_{2}} e^{\varepsilon_{i t}},
$$

which after being logarithmed will take the form:

$$
\ln K S W P_{i t}=\ln \alpha_{0}+\alpha_{1} \ln S D W P_{i t}+\alpha_{2} \ln D N W P_{i t}+\varepsilon_{i t}
$$

The determined on their basis elasticity coefficients may contribute to formulating conclusions related to the necessity for improving working conditions if an entrepreneur wants to improve the work efficiency of employees and decrease the costs associated with accidents at work. Indirectly, the analysis can contribute to appropriate management of an enterprise through application of tools and solutions that allow to reduce (or eliminate) the number of undesirable occurrences. In other words, to decrease the number of accidents and the costs related to them.

While analysing the influence of explanatory variables in particular provinces on analysed costs of benefits the authors applied dummy variables, as a model with artificial variables, in case of a set of concrete, determined objects, produces reliable results in the factual and statistical sense. The OLS (Ordinary Least Squares) method and GRETL package were used to estimate the model.

The analyses make use of the data that comes from the publication by the Central Statistical Office, i.e. "Working conditions in the years 2010-2017", "Accidents at work in the years 2010-2017", "Statistical Yearbook of the Regions - Poland in the years 2010-2017" as well as databases of local branches of the Central Statistical Office (CSO - Statistics Poland).

\section{RESULTS}

\subsection{Accident analysis - selected issues}

An analysis of the accident ratio development in eight consecutive years in particular provinces of our country was adopted in order to determine the security level and for the purpose of further comparative analyses. 
Table 1

Changes in an accident ratio in Polish provinces in the years 2010-2017 (compared to the previous year)

\begin{tabular}{|l|c|c|c|c|c|c|c|c|}
\hline \multirow{2}{*}{ Years } & $\mathbf{2 0 1 1}$ & $\mathbf{2 0 1 2}$ & $\mathbf{2 0 1 3}$ & $\mathbf{2 0 1 4}$ & $\mathbf{2 0 1 5}$ & $\mathbf{2 0 1 6}$ & $\mathbf{2 0 1 7}$ \\
\cline { 2 - 9 } Provinces & \multicolumn{7}{|c|}{ absolute numbers } \\
\hline Lower Silesian Voivodeship & 1.01 & 0.96 & 0.93 & 0.96 & 0.97 & 0.96 & 0.99 \\
\hline $\begin{array}{l}\text { Kuyavian-Pomeranian } \\
\text { Voivodeship }\end{array}$ & 1.01 & 0.97 & 0.97 & 0.98 & 1.01 & 0.93 & 0.99 \\
\hline Lublin Voivodeship & 0.93 & 0.96 & 1.02 & 0.98 & 0.96 & 1.04 & 0.97 \\
\hline Lubusz Voivodeship & 1.03 & 0.94 & 0.92 & 0.98 & 0.88 & 1.04 & 0.97 \\
\hline Lodz Voivodeship & 1.01 & 0.95 & 0.96 & 1.02 & 0.97 & 0.97 & 0.97 \\
\hline Lesser Poland Voivodeship & 0.98 & 0.94 & 0.98 & 1.02 & 0.95 & 0.97 & 0.97 \\
\hline Masovian Voivodeship & 1.10 & 0.91 & 1.00 & 0.97 & 0.94 & 0.97 & 0.98 \\
\hline Opole Voivodeship & 0.97 & 0.91 & 1.03 & 0.95 & 0.97 & 1.04 & 0.95 \\
\hline Subcarpathian Voivodeship & 1.02 & 0.90 & 0.95 & 1.05 & 0.96 & 0.98 & 1.00 \\
\hline Podlaskie Voivodeship & 0.96 & 0.93 & 1.03 & 0.93 & 0.98 & 1.02 & 1.03 \\
\hline Pomeranian Voivodeship & 1.02 & 0.90 & 1.01 & 0.93 & 0.99 & 0.92 & 0.99 \\
\hline Silesian Voivodeship & 0.97 & 0.92 & 0.94 & 0.99 & 1.00 & 0.96 & 1.01 \\
\hline Holy Cross Province & 0.99 & 0.87 & 0.95 & 1.03 & 1.00 & 1.04 & 1.00 \\
\hline $\begin{array}{l}\text { Warmian-Masurian } \\
\text { Voivodeship }\end{array}$ & 0.98 & 0.99 & 0.93 & 1.01 & 0.99 & 0.98 & 0.92 \\
\hline Greater Poland Voivodeship & 1.08 & 0.92 & 0.98 & 0.99 & 0.94 & 0.99 & 0.93 \\
\hline $\begin{array}{l}\text { West Pomeranian } \\
\text { Voivodeship }\end{array}$ & 0.98 & 0.96 & 1.03 & 1.04 & 0.93 & 0.98 & 0.91 \\
\hline
\end{tabular}

The ratio does not include employees of civilian budget units conducting activity in the scope of national defence and public security.

Source: Own calculations on the basis of database-3 GUS, https://stat.gov.pl

While analysing the accident ratio one may observe that in 2017, compared to 2016, its increase was recorded only in two provinces, namely the Podlaskie Province (by $3 \%$ ) and the Silesian Province (by 2 percentage point less). In the last year covered by the research the largest drop of the ratio can be observed in the West Pomeranian Province (by approx. 9\%). Therefore, in this province the accident ratio dropped to the level of 7.57 (injured per 1000 of employed persons) (Table 1).

Being in the possession of comparable accident statistics in the analysed period, the authors subsequently conducted an analysis of accidents determining the share of injured persons with reference to sustained injuries, based on the adopted classification that included lighter, serious and fatal accidents. 


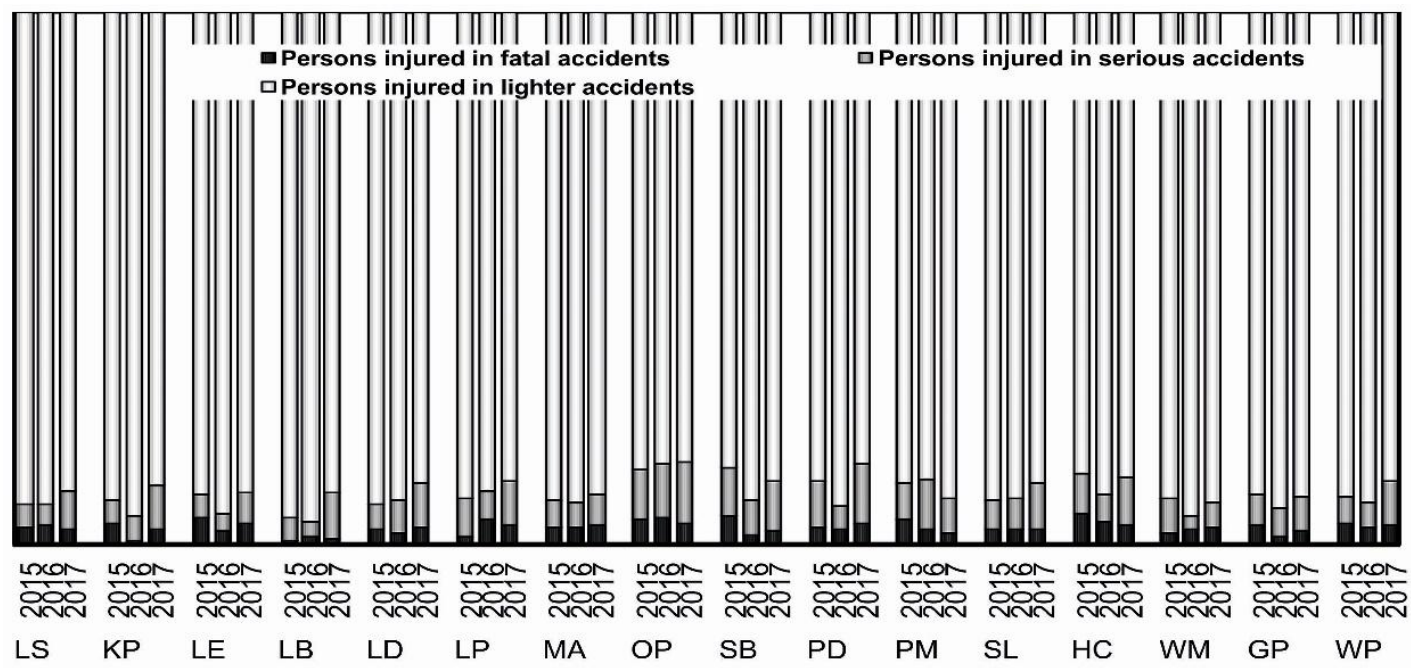

where LS - Lower Silesian Voivodeship. KP - Kuyavian-Pomeranian Voivodeship. LE - Lublin Voivodeship. LB Lubusz Voivodeship. LD - Lodz Voivodeship. LP - Lesser Poland Voivodeship. MA - Masovian Voivodeship. OP Opole Voivodeship. SB - Subcarpathian Voivodeship. PD - Podlaskie Voivodeship. PM - Pomeranian Voivodeship. SL - Silesian Voivodeship. HC - Holy Cross Province, WM - Warmian-Masurian Voivodeship. GP - Greater Poland Voivodeship. WP - West Pomeranian Voivodeship

Fig. 1. Share of injured persons depending on the accident outcome in the total number of injured in accidents according to Polish provinces in the years 2015-2017

Source: Own calculations on the basis of database-2 GUS, https://stat.gov.pl

While analysing the Figure it is possible to draw a conclusion that in each province lighter accidents constitute a dominant share of the number of the injured (over $98.44 \%$ ). The remaining two groups constitute a small share (frequently they account for less than $1 \%$ of all accidents).

In case of the Silesian Province in the years 2015 and 2017 compared to the previous year the number of people injured in minor accidents at work increased. Of all these three years the slightest growth occurred in 2015 - by approx. $0.2 \%$. The situation was different in 2016 - one can observe a drop in the number of the injured. In addition, a growth was recorded in the Silesian Province in each type of accident, but only in 2017.

However, as lighter accidents seem to be dominant the analysis needs to include also the serious and fatal ones. Although the second type of accidents is more common, in the perspective of all the analysed years compared to the previous year, the largest change has been recorded in relation to fatal accidents - the largest growth in 2017 in the Kuyavian-Pomeranian Province (from 3 to 14 victims) and in 2015 in the Holy Cross Province (from 2 to 12 victims), and the largest drop in 2016 in the KuyavianPomeranian region (from 21 to 3 people) and the Holy Cross Province (from 12 to 2 people).

However, it needs to be stressed that the type of accident, and more precisely the type of its consequences, is closely related to the situation of people who suffered permanent or long-term damage to their health as a result of an accident and have been receiving pension on this basis. Although the analysis of the number of people receiving pensions after the accident provides an outlook on the scale of the problem, only turning attention to the costs of these pensions allows for determining the volume of economic effects. Benefits received from the employer or the Social Security Office (ZUS) do not always reward the losses caused by an accident at work occurrence. 


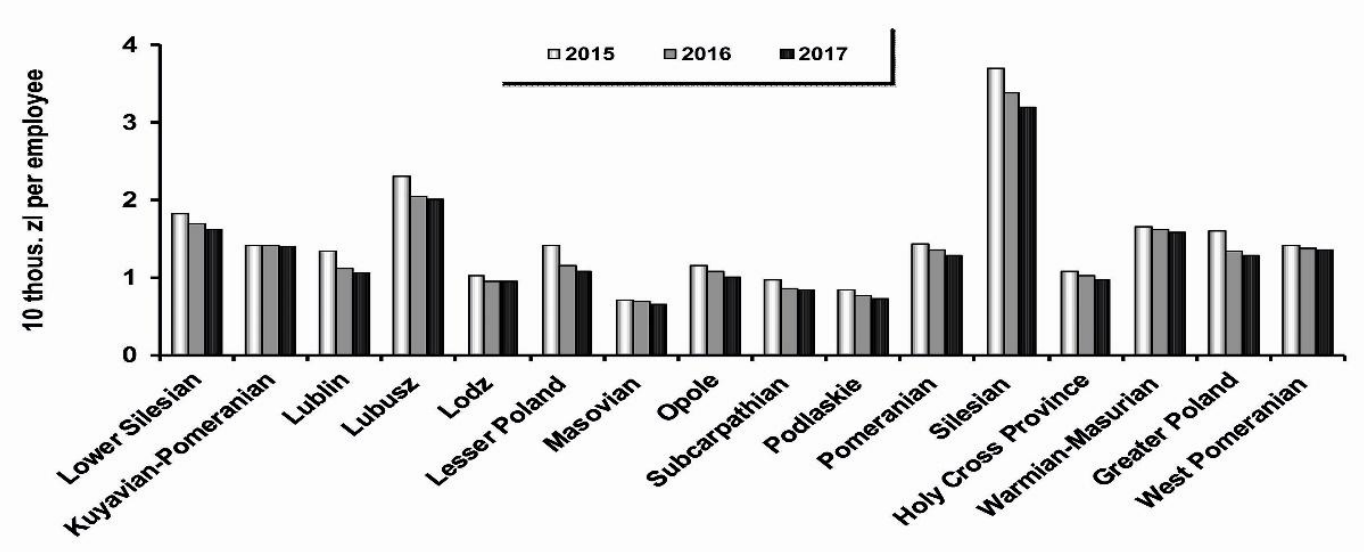

Fig. 2. Costs of benefits of persons who receive accident pensions due to inability to work caused by the consequences of an accident at work per the number of employed persons in

Polish provinces in the years 2015-2017

Source: Own calculations on the basis of database-1 GUS, https://stat.gov.pl

On the basis of figure 2 it is possible to observe that in the last three years of the research the costs of pensions for persons receiving accident pensions due to inability to work caused by consequences of an accident at work per an employed person were highest in the Silesian Province. This can be explained by the type of industry that is characteristic for this region. The lowest values of this rate were recorded in the Masovian Province.

\subsection{A space-time analysis}

In this part of the paper the authors attempted to estimate the cost level of benefits due to accidents at work. Due to the fact that costs of an entrepreneur's expenses primarily depend on the number of benefits due to accidents at work and the number of days with inability to work caused by accidents at work, these factors were used to explain the costs.

After equation (1) was logarithmed the following estimation was received:

$$
\ln K \hat{S} W P_{i t}=\underset{(17,694)}{7,152+17,236)} \underset{(2,822}{\ln } S D W P_{i t}+\underset{(2,502)}{0,188 \ln D N W P_{i t}}
$$

where: $\ln K S W P_{\text {it }}-\ln$ cost of benefits due to accidents at work for an $i$-th province in $t$ time; $\ln S D W P_{\text {it }}-\ln$ number of benefits due to accidents at work for an $i$-th province in $t$ time; $\ln D N W P_{\text {it }}-\ln$ number of days with inability to work caused by accidents at work for an $i$-th province in $t$ time; $\mathrm{i}=1, \ldots, 16 ; \mathrm{t}=1, . ., 8$; values of t-Student statistics were included in the brackets.

On the basis of the above equation one can conclude that the impact of the number of benefits due to accidents at work is less than proportional - an increase of SDWP by $1 \%$ results in the growth of analysed costs on average by $0.82 \%$. This means that the level of the number of benefits grows faster than the level of the explanatory value. The situation is similar when days of inability to work after the accident at work are considered. Here, the growth by $1 \%$ results in the growth of analysed costs on average by $0.188 \%$.

In the presented model the number of observations was 128 , autocorrelation was not present $(r=0,149)$, and the relative error committed while applying the assessed model amounted to $1.84 \%$. The $p$-value for all the presented variables was smaller than 0.00001 , and the costs of benefits following an accident at work were explained by the 
model in $80 \%$, however, $F(2,125)=251,54$ at $p=152 \mathrm{e}-44$.

Decomposition of the constant into 16 parts that correspond to particular provinces allowed to capture effects characteristic for given regions. Figure 3 presents the impact of explanatory variables on the dependent variable (in a multiplicative grasp).

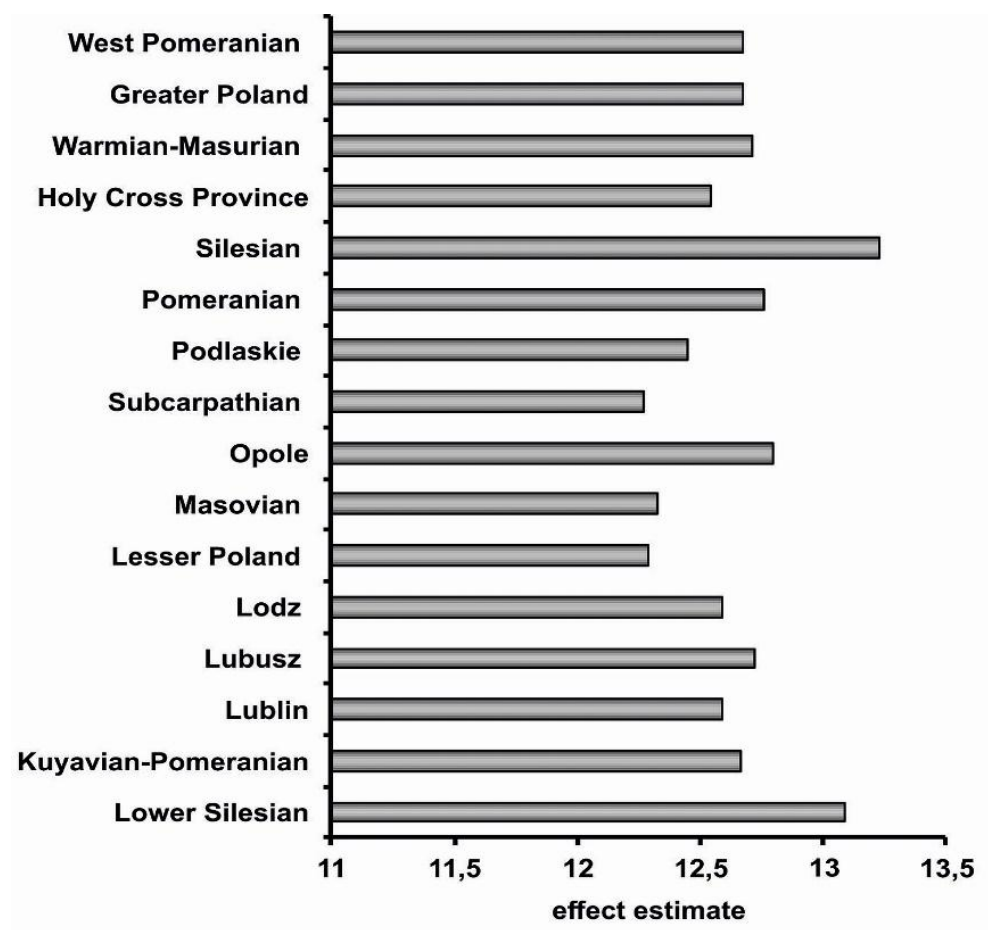

Fig. 3. Impact of number of benefits due to accidents at work and number of days of inability to work caused by accidents at work on costs of benefits due to accidents at work in Polish provinces (years 2010-2017)

Source: own calculations using the GRETL package, https://bgl.stat.gov.pl/BDL/start

Based on the information included in figure 3 one can observe that the highest influence of explanatory variables on the cost of benefits due to accidents at work was recorded in the Silesian Province, the smallest one in turn was recorded in the Subcarpathian Province.

\section{DISCUSSION}

The analysis of the world literature shows that despite the permanent technical and technological progress, ever higher competences of OSH (Occupational safety and health) staff, constant improvements in the area of work organisation and developing an advanced safety culture, the issue of accidents at work is still valid (Allahyari et al., 2014). Accidents at work, besides their purely humanitarian and image aspect, also have their economic dimension (Reniers and Brijs, 2014). According to numerous experts, general costs of accidents at work on average range from $1 \%$ to $4 \%$ of national income and according to the estimates by International Labour Organization (ILO) they can even reach the level of 4\% of GDP (Serafińska and Rzepecki, 2004; Rydlewska-Liszkowska, 2006). The European Agency for Safety and Health at Work (EU-OSHA) in turn announced that the total losses caused by accidents at work in the countries of the old EU-15 range from 2.6\% and 5.9\% of GDP (Rzepecki, 2012). Noncompliant with the requirements of ergonomics and occupational health and safety regulations conditions of the working environment generate real threats to the 
life and health of employees (Dźwigarek, 2004). This can be confirmed by the estimations of ILO, according to which in 2008, in the global dimension, over 320 thousand of people suffered lethal accidents and 317 million of people were injured in accidents at work, where in consequence the sickness absence lasted for longer than 3 days (Krzyśków et al., 2015). Such grave consequences of threats at work in the humanitarian perspective mean suffering of the injured and their nearest and dearest (Macdonald, 2012), and in the social and economic dimension serious losses for the company, insuring institutions and the whole society (Węgrzyn, 2017). From this perspective, social costs of accidents at work, while generating significant economic losses, constitute the type of costs transferred to the whole society, burdening the Social Security Office (ZUS) and the health-care system (Rzepecki, 2014).

The rank of the problem related to accidents at work does not result exclusively from the number of injuries, costs of their treatment, benefits for accidents at work, that is factors that are included into the so called tip of the iceberg of H.W. Heinrich (Karczewski, 2000). This also concerns so called alternative costs, that is costs of lost opportunities, associated with production processes disturbances, lost time, overtime, costs of material damage, destroyed buildings, equipment and materials, production delays, decreased quality and capacity, repairs or exchanges, costs of life-saving equipment, medical assistance and transport and lost incomes, finally loss of reputation (Rzepecki, 2014). A high accident ratio proves a faulty organisation of the work safety system, lack of competences, insufficient motivation to develop friendly working conditions and low level of organisational culture (Wachter and Yorio, 2014). The presented analyses prove that a vital importance needs to be attributed to economic stimulators of working conditions improvement, which have been functioning in the form of a differentiated accident insurance premium. These instruments, which have an impact on the reduction in the number of accidents, reduction, consist in determining the amounts of the accident insurance premiums depending on the costs of these accidents, accident frequency or severity ratios in particular types of business activity or enterprises. A differentiated premium at the level of the payer depends on the category of risk determined, among others, by frequency ratios of the total number of injured in accidents at work and injured in serious or fatal accidents (Pawłowska and Rzepecki, 2000; Rzepecki, 2006). Therefore, it can be speculated that also this aspect related to the cost-efficiency significantly contributes to care for reduction of serous and fatal accidents.. This thesis can be confirmed by the fact that the conducted research has shown that lighter accidents constitute over $98 \%$ of all accidents at work. Exceptions to the safe process of work, which cause disturbances to the production process, generate losses in the form of accidents. It seems right then to quote a metaphor formulated by Smoliński and Solecki, which compares fatal and serious accidents to a log thrown into the cogs of a machine and stops its operation, which happens quite rarely. However, lighter accidents, as occurrences much more frequent, can be compared to a branch that slows down or blocks, but very rarely stops the whole machinery. Yet, these branches by the very fact of contributing to the disturbances cause that the whole machine consumes more energy to break them, overcome them and keep functioning (Smoliński and Solecki, 2015).

An interesting observation results also from the analysis of the impact that the number of benefits due to accidents at work and days of inability to work have on costs of benefits for the accident, which is the highest in the Silesian region, the lowest level of 
impact in turn occurs in the Subcarpathian Province. This is probably related to the specificity of the Silesian Province, traditionally associated with hard coal mining. The majority of currently active coal mines in Poland are located in this area. The coal mines functioning within the Silesian mining sector include 15 coal mines which are concentrated within the Kompania Węglowa, 5 coal mines concentrated in Jastrzębska Spółka Węglowa and 4 mines associated in Katowicki Holding Węglowy. This means that enterprises characterised by high or increased accident risk, which consistently for many years include enterprises that belong to activity groups that comprise coal mining and quarrying of energy producing materials, employ about 114 thousand of persons. Apart from the mining sector also the steel industry is well developed in this region. Several ironworks and several installations (i.e. parts of ironworks, e.g. rolling mills, steel works, pipe mills) have been functioning here, which are also included into the group of accident-prone sections of the economy (Urząd Marszałkowski Województwa Śląskiego, 2013). Traditionally, the industrial nature of the Silesian Province can be compared to a diversified branch structure of the industry in the Subcarpathian Province, alongside a high ratio of innovative industrial companies that amounts almost to $21 \%$ (which constitutes the first position in the country). The innovative industry of the Subcarpathian region includes, among others, aviation and IT industries (e.g. the aviation industry cluster - Dolina Lotnicza; Mielecki Park Przemysłowy) (Sejmik Województwa Podkarpackiego w Rzeszowie, 2013).

Moreover, based on the conducted research one can draw a conclusion that it is the Silesian region where the costs of accident pensions are the highest, while in the Subcarpathian region these costs are at one of the lowest levels.

\section{CONCLUSION}

The importance of the high level of health and safety at work as determinants of the competitive advantage of an organisation, region or national economy is not appreciated and utilised enough. The discussion on the economic issues related to health and safety at the workplace result from the fact that there exist mutual relationships between safety and economic categories. Therefore, it is possible in this context to distinguish and study of the analysed economic features and their determinants. Such an approach allows for acquisition of information that is indispensable for effective health and safety management, because of these economic categories. The analysis of these categories has confirmed the fact that the largest influence of the costs of benefits due to accidents at work, with the distinguished variables, was recorded in the Silesian Province and the slightest influence was recorded in the Subcarpathian Province. Furthermore, on the basis of our research, is possible to draw a conclusion that the level of the number of benefits due to accidents at work and days of inability to work after the accident at work grow faster than the level of the explained value.

Optimisation of economic involvement (of an enterprise, region) in the activities aimed at protecting health at work should ensure such a level of work safety for which the relationship between the costs resulting from improper conditions of working environment and costs of preventive actions will be most favourable, that is the total costs related to $\mathrm{OSH}$ will be minimal.

To sum up, a very important issue of health and safety is the economic analysis of the costs related to any disturbances that can occur in the system man-technical object- 
environment, as well as benefits that can result from preventive actions aimed at minimising the risk related to functioning of all the system's elements.

However, it needs to be stressed that the presented analysis is a preliminary research, whose development may contribute to an improvement in health and safety conditions in organisations.

\section{REFERENCES}

Allahyari, T., Rangi, N.H., Khalkhali, H., Khosravi Y., 2014. Occupational Cognitive Failures and Safety Performance in the Workplace. International Journal of Occupational Safety and Ergonomics (JOSE), 20(1), 175-180.

DOI: $10.1080 / 10803548.2014 .11077037$

Battaglia, M., Frey, M., Passetti, E., 2014. Accidents at work and costs analysis: a field study in a large Italian company. Industrial Health, 52(4), 354-366.

Bayram, M., Ungan, M.C., Ardic, K., 2017. The relationships between OHS prevention costs, safety performance, employee satisfaction and accident costs. International Journal of Occupational Safety and Ergonomics (JOSE) 23(2), 285296. DOI: $10.1080 / 10803548.2016 .1226607$

Bayram, M., Ungan, M.C., 2018. The relationships between OHS prevention costs, OHSMS practices, employee satisfaction, OHS performance and accident costs. Total Quality Management \& Business Excellence.

DOI: 10.1080/14783363.2018.1480897

Bellamy, L.J., Manuel, H.J, Oh, J.I.H., 2014. Investigated Serious Occupational Accidents in The Netherlands. 1998-2009, International Journal of Occupational Safety and Ergonomics (JOSE), 20(1), 19-32.

DOI: $10.1080 / 10803548.2014 .11077033$

Carrillo-Castrillo, J.A., Rubio-Romero, J.C., Onieva, L., 2013. Causation of Severe and Fatal Accidents in the Manufacturing Sector. International Journal of Occupational Safety and Ergonomics (JOSE), 19(3), 423-434.

DOI: 10.1080/10803548.2013.11076999

Dźwiarek, M., 2004. An Analysis of Accidents Caused by Improper Functioning of Machine Control Systems. International Journal of Occupational Safety and Ergonomics (JOSE), 10(2), 129-136. DOI: 10.1080/10803548.2004.11076601

European Commission, 2011. Socio-economic costs of accidents at work and workrelated ill health. Manuscript of Directorate-General for Employment, Social Affairs and Inclusion, Luxembourg.

GUS, database-1, Working conditions in the years 2010-2017, https://stat.gov.pl (available 20.11.2018).

GUS, database-2, Accidents at work in the years 2010-2017, https://stat.gov.pl (available 20.11.2018).

GUS, database-3, Statistical Yearbook of the Regions - Poland in the years 20102017, https://stat.gov.pl (available 20.11.2018).

GUS, databases of local branches of the Central Statistical Office, https://bgl.stat.gov.pl/BDL/start (available 20.11.2018).

Karczewski, J.T., 2000. Systemy zarządzania bezpieczeństwem pracy. ODDK, Gdańsk.

Krzyśków, B., Ordysiński, S., Pawłowska, Z., Pęciłło-Pacek, M., 2015. Badanie wypadków przy pracy. Materiał źródłowy dla uczestników szkolenia, Centralny 
Instytut Ochrony Pracy - Państwowy Instytut Badawczy, Warszawa.

Macdonald, D.J.M., Sanati, K.A., Macdonald E.B., 2012. The Costs and Characteristics of Occupational Injuries Admitted to a Trauma Unit. International Journal of Occupational Safety and Ergonomics (JOSE), 18(4), 587-590.

Pawłowska, Z., Rzepecki, J., 2000. Impact of economic incentives on costs and benefits of occupational health and safety. International Journal of Occupational Safety and Ergonomics (JOSE), Spec No, 71-83,

DOI: $10.1080 / 10803548.2000 .11105109$

Reniers, L.L.G., Brijs, T., 2014. An Overview of Cost-benefit Models/Tools for Investigating Occupational Accidents. Chemical Engineering Transitions, 36, 4348, DOI: 10.3303/CET1436008.

Rzepecki, J., 2006. Składki i świadczenia z ubezpieczenia wypadkowego ZUS funkcjonowanie systemu. Bezpieczeństwo Pracy: nauka i praktyka, 11, 22-25.

Rzepecki, J., 2012. Społeczne koszty wypadków przy pracy. Bezpieczeństwo Pracy: nauka i praktyka, 5, 20-23.

Rzepecki, J., 2014. Społeczne koszty wypadków przy pracy- pilotażowe wdrożenie metody obliczania. Bezpieczeństwo Pracy: nauka i praktyka, 5, 16-19.

Rydlewska-Liszkowska, I., 2006. Koszty chorób zawodowych i wypadków przy pracy w Polsce. Medycyna Pracy, 57(4), 317-324.

Sejmik Województwa Podkarpackiego w Rzeszowie, 2013. Strategia rozwoju województwa - podkarpackie 2020, Rzeszów,

https://umwp.podkarpackie.pl/.../STRATEGIA-ROZWOJU-WOJEWODZTWA-PODK... (available 20.11.2018)

Serafińska, A., Rzepecki, J., 2004. Koszty wypadków przy pracy w Polsce. Prewencja i Rehabilitacja - kwartalnik ZUS, 3, 1-3.

Smoliński, D., Solecki, L., 2015. Ekonomiczne przesłanki ograniczania ryzyka zawodowego. Bezpieczeństwo Pracy: nauka i praktyka, 6, 25-27.

Treaty establishing EC. The legal status of the current day: 21.11.2018 https://www.lexlege.pl/traktat-ustanawiajacy-we/art-137/ (available 21.11.2018)

Urząd Marszałkowski Województwa Śląskiego, 2013. Strategia Rozwoju Województwa Śląskiego „ŚLĄSKIE 2020+”, Katowice, https://rpo.slaskie.pl/file/download/201 (available 20.11.2018)

Wachter, J.K., Yorio, P.L., 2014. A system of safety management practices and worker engagement for reducing and preventing accidents: an empirical and theoretical investigation. Accident Analysis and Prevention, July, 68, 117-130. DOI: 10.1016/j.aap.2013.07.029

Węgrzyn, M., 2017. Analiza danych dotyczących przyczyn wypadków przy pracy oraz liczby osób poszkodowanych w tych wypadkach w Polsce, w latach 2010-2015. Zeszyty Naukowe Szkoły Głównej Służby Pożarniczej, 62, 1(2), 185-201. 